\title{
Marlojong sebelum Perkawinan: Kiat Adat Menghadapi Wali 'Aḍal di Ranah Batahan, Pasaman Barat
}

\author{
Salma ${ }^{1}$, Syahril $^{2}$ \\ ${ }^{1}$ Universitas Islam Negeri Imam Bonjol, Padang - Indonesia \\ ${ }^{2}$ KUA Kecamatan Lembah Melintang, Pasaman Barat - Indonesia \\ e-mail: salma@uinib.ac.id
}

\begin{abstract}
This article aims to analyze and explore the tradition of marlojong before marriage in Ranah Batahan, West Pasaman. Marlojong is the act of a couple who is not approved by their parent (wali) for certain reasons by running to the house of the elder of custom (tetua adat) or a respected family. The elopement could reduce the dignity of women and their parents. So, it becomes a reason for the traditional elders to call them. The data were collected by observation and in-depth interviews with couples who did marlojong, parents of each couple, other nuclear families, traditional elders, KUA officials and local scholars. The data was analyzed by reduction, display and verification. The results showed that the meaning of marlojong was actually not only a couple who fled to the house of the traditional elders but also the efforts to overcome the guardian's reluctance (wali 'adal) and reduce the parobanan (brideprice). Therefore, the causes of marlojong were overcoming the reluctant of parents and the high level of brideprice. On one side, the marlojong was seen as negative but on the other hand, it became a customary way to resolve the guardian's reluctance (wali 'adal) without having to go to a religious court.
\end{abstract}

Tulisan ini bertujuan untuk menganalisis dan mendalami tradisi marlojong sebelum perkawinan di Ranah Batahan Pasaman Barat. Marlojong adalah perbuatan pasangan yang tidak disetujui oleh orang tua (wali) karena alasan tertentu dengan cara melarikan diri ke rumah kepala adat atau orang yang disegani. Pelarian itu dipandang dapat menurunkan harga diri perempuan dan orang tuanya, sehingga menjadi alasan tetua adat untuk memanggil mereka. Data penelitian lapangan ini dikumpulkan dengan cara observasi dan wawancara mendalam dengan pasangan yang melakukan marlojong, orang tua masing-masing pasangan, keluarga inti lainnya, tetua adat, pejabat KUA dan ulama lokal. Data dianalisis dengan cara reduksi, display dan verifikasi. Hasil penelitian menunjukkan bahwa makna marlojong sebenarnya tidak hanya sekedar pasangan yang melarikan diri ke rumah tetua adat tetapi lebih kepada upaya mengatasi keengganan wali (wali 'adal) dan pelemahan terhadap tradisi parobanan. Oleh karena itu, sebab-sebab marlojong di antaranya adalah untuk mengatasi keengganan orang tua dan tingginya parobanan. Pada satu sisi, marlojong dipandang negatif, tetapi pada sisi lain menjadi jalan keluar adat untuk menyelesaikan wali 'adal tanpa harus pergi ke pengadilan agama.

Keywords: marriage; guardian's reluctant; wali 'adal; tradition; marlojong; khitbah 
Salma, Syahril

\section{Pendahuluan}

Wali bagi perempuan merupakan salah satu syarat yang harus dipenuhi sebelum melaksanakan akad perkawinan. Keberadaan dan izin seorang wali menjadi penentu sah atau tidaknya satu akad perkawinan. Dalam Pasal 45 sampai 54 Undang-Undang No. 1 Tahun 1974 tentang Perkawinan, diatur tentang hak dan kewajiban orang tua dan anak serta perwalian. Kemudian Kompilasi Hukum Islam menjelaskannya secara lebih rinci. Berdasarkan ketentuan itu, wali merupakan unsur yang harus ada dalam akad perkawinan. Keharusan keberadaan wali ini tidak hanya termaktub dalam peraturan perundangan di Indonesia, tetapi juga dicantumkan dalam peraturan perundangan negara-negara lain seperti Brunei Darussalam. ${ }^{1}$ Adapun pernikahan anak dengan wali yang tidak layak, dibatalkan oleh Mahkamah Syari'ah di Negeri Sembilan Malaysia.2 ${ }^{2}$ Dalam hadis Rasulullah disebutkan bahwa tidak sah nikah seorang perempuan tanpa adanya wali (lā nikāḥ illā bi waliy wa shāhiday 'adl). Dalam hadis lain juga ditemukan adanya hak memaksa seorang ayah sebagai wali untuk menikahkan anak perempuannya. Bahkan dalam pandangan Ibn Ḥazm, seorang perempuan janda juga mesti dinikahkan oleh walinya. ${ }^{3}$ Dalam konteks memahami hadis ini, para ulama berbeda pendapat ketika perempuan yang akan menikah itu telah dewasa dan bisa bertindak secara hukum atas dirinya sendiri.

Kudhori mengemukakan bahwa hadis tentang wali ijbārī ini derajatnya shadh, sehingga hadis ini berseberangan dengan hadis-hadis sahih lain yang memberikan kebebasan kepada seorang perempuan untuk memilih calon suami. ${ }^{4}$ Ketika ada seorang perempuan yang tidak mematuhi ayahnya dengan

${ }^{1}$ Nurol Huda binti Pehin Datu Seri Maharaja, "Wali Nikah dalam Fiqh dan Penerapannya dalam Undang-Undang Keluarga Islam Brunei (Pindaan 2012)," Nurani: Jurnal Kajian Syariah dan Masyarakat 17, no. 1 (2017): 1-14.

${ }^{2}$ Abdul Fattah Wan Ismail et al., "Faraq Perkahwinan bagi Pasangan Tak Sah Taraf di Negeri Sembilan - Judicial Separation of Illegal Marriage in Negeri Sembilan," International Journal of Islamic Thought13, no. June (2018): 124-34, https://doi.org/10.24035/ijit13.2018.012.

${ }^{3}$ Ahmad Fauzi, "Pemikiran Ibn Hazm tentang Keberadaan Wali Nikah dalam Perkawinan Janda," Al-Ihkam: Jurnal Hukum dan Pranata Sosial 8, no. 2 (2014): 300-333, https://doi.org/10.19105/alihkam.V8I2.352.

4Muhammad Kudhori, "Hak Perempuan dalam Memilih Suami (Telaah Hadis Ijbār Wali)," AlIhkam: Jurnal Hukum dan Pranata Sosial 12, no. 1 (2017): 1-23, https://doi.org/10.19105/alihkam.v12i1.1213. 
menolak calon suami pilihan ayahnya maka anak perempuan tersebut tidak tergolong sebagai anak durhaka. Sejalan dengan hal ini, Tulab mengemukakan bahwa wali dalam pandangan Hanafiyah merupakan syarat kamāl (penyempurna) dan bukan syarat sah dalam perkawinan. ${ }^{5}$ Artinya, ketiadaan wali tidak membatalkan akad perkawinan. Menurut Setiawan, nikah sirri tetap sah selama syarat dan rukun nikahnya terpenuhi, ${ }^{6}$ di antaranya keharusan adanya wali. Ketika nikah sirri itu tanpa wali, pernikahannya tidak sah. Oleh karena itu, pandangan Ḥanafiyah ini lebih sejalan dengan konsep kesetaraan gender, selama perempuan yang akan menikahkan dirinya itu setara dengan laki-laki pilihannya. Di antara polemik yang tidak berkesudahan adalah tentang wali dalam pernikahan tidak tercatat (nikah siri atau nikah di bawah tangan). Selain itu, anak yang dilahirkan akibat nikah siri tetap mempunyai hubungan keperdataan, termasuk hubungan wali nikah, antara ayah dengan anak perempuannya. ${ }^{7}$

Seorang perempuan yang telah memutuskan untuk menikah dengan seorang laki-laki, tetapi laki-laki itu tidak disetujui oleh wali, dalam hal ini ayahnya, maka peraturan perundangan menegaskan bahwa perempuan tersebut memiliki hak untuk mengajukan wali 'adal (wali yang enggan) ke pengadilan agama. Dalam hal ini, ayah sebagai wali yang tidak bersedia menikahkan anak perempuannya dengan calon suami pilihannya sendiri karena alasan tertentu, akan berhadapan dengan anak perempuannya itu di sidang pengadilan agama. Berdasarkan hal itu, pengadilan agama (hakim) dapat menilai kelayakan lakilaki itu dari sudut pandang syarak sebagai calon suami. Jika pengadilan tidak menemukan hal atau sesuatu yang lain untuk menghalanginya menjadi suami, negara melalui keputusan pengadilan agama mengambil alih kewenangan ayah sebagai wali anak perempuannya dan perempuan itu dinikahkan oleh wali hakim yang ditetapkan dalam putusan.

5Tali Tulab, "Tinjauan Status Wali dalam Perkawinan Berdasar Pendekatan Feminis," Ulul Albab: Jurnal Studi dan Penelitian Hukum Islam 1, no. 1 (2017): 152-64, https://doi.org/10.30659/jua.v1i1.2223.

6Eko Setiawan, "Fenomena Nikah Siri dalam Perspektif Sosiologi Hukum," Justicia Islamica 13, no. 1 (2016): 135-155, http://jurnal.stainponorogo.acid/index.php/justicia/article/view/456.

${ }^{7}$ Arne Huzaimah, "Pandangan Hakim Pengadilan Agama Palembang terhadap Putusan Mahkamah Konstitusi Nomor 46/PUU-VIII/2010 tentang Status Anak di Luar Nikah," Intizar 20, no. 1 (2014): 63-82. 
Salma, Syahril

Peluang yang diberikan negara untuk menyelesaikan konflik pemilihan pasangan hidup antara anak dengan ibu dan bapaknya, tidak selalu termanfaatkan secara baik. Banyak pasangan yang memilih cara berbeda untuk menunjukkan sikap mereka terhadap penolakan orang tua terhadap pasangan hidup yang dipilihnya. Umumnya, cara yang diambil pasangan ini adalah dengan keluar atau mengasingkan diri dari keluarga. Banyak nama, sebutan atau ungkapan yang diberikan masyarakat terhadap sikap mengeluarkan diri atau melarikan diri dari keluarga dengan tujuan untuk menikah meskipun tidak disetujui oleh kedua orang tuanya. Saladin menyebutkan bahwa dalam suku Sasak, ditemukan tradisi merari yaitu kawin lari (lari atau melarikan perempuan) ${ }^{8}$ dan Haq menyebutkan, tradisi suku Sasak itu sebagai perbuatan "mencuri" calon pengantin perempuan atas persetujuan dirinya dengan tujuan untuk memusyawarahkan (selabar) dalam menyepakati pembayaran ajikrame dan pisuke guna menuju perdamaian para pihak. ${ }^{9}$

Wagianto menjelaskan bahwa ada tradisi kawin colong pada masyarakat Osing Banyuwangi, yaitu suatu perbuatan seorang laki-laki mencuri atau melarikan seorang perempuan untuk dijadikan istrinya tanpa sepengetahuan orang tua pihak perempuan. ${ }^{10}$ Sudantra menyebutkan adanya tradisi $n g e r o r o d$ (kawin lari) di Desa Pakraman Bali.11 Yelepele mengemukakan tentang model kawin lari dalam masyarakat Muslim Suku Dani di Papua. ${ }^{12}$ Heselum wuni, dulunya berbentuk kegiatan di mana para pasangan remaja laki-laki dan perempuan berhadap-hadapan sambil menyajikan syair-syair cinta secara ber-

8Bustami Saladin, "Tradisi Merari' Suku Sasak di Lombok dalam Perspektif Hukum Islam," AlIhkam: Jurnal Hukum dan Pranata Sosial 8, no. 1 (2014): 21-39, https://doi.org/10.19105/alihkam.V8I1.338.

${ }^{9}$ Hilman Syahrial Haq dan Hamdi Hamdi, "Perkawinan Adat Merariq dan Tradisi Selabar di Masyarakat Suku Sasak," Perspektif 21, no. 3 (2016): 157-67, https://doi.org/10.30742/ perspektif.v21i3.598.

10Ramdan Wagianto, "Tradisi Kawin Colong pada Masyarakat Osing Banyuwangi Perspektif Sosiologi Hukum Islam," Al-Ahwal: Jurnal Hukum Keluarga Islam 10, no. 1 (2017): 61-84, http://ejournal.uin-suka.acid/syariah/Ahwal/article/view/10106.

11I Ketut Sudantra, I Made Walesa Putra, dan Yuwono Yuwono, "Aspek-aspek Hukum Keluarga dalam Awig-Awig Desa Pakraman," Jurnal Magister Hukum Udayana (Udayana Master Law Journal) 5, no. 1 (2016): 43-58, https://doi.org/10.24843/JMHU.2016.v05.i01.p05.

12 Umar Yelepele dan Moh. Hefni, "Perkawinan Adat Muslim Suku Dani di Papua," Al-Ihkam: Jurnal Hukum dan Pranata Sosial 7, no. 1 (2013): 17-51, https://doi.org/10.19105/alihkam.v7i1.317. 
sahut-sahutan dengan tujuan untuk menarik hati pasangan. Apabila ada respon, biasanya juga dibalas dengan nyanyian yang sama. Ini berarti cintanya diterima oleh pasangan yang ditaksir. Adakalanya dalam sebuah kesempatan, mereka bisa kawin lari setelah perayaan itu. Ini bisa terjadi pada pasangan remaja yang sudah cukup matang dengan tujuan untuk menemukan jodoh. Menurut Pattiroy, tingginya doi ' menre' atau uang belanja untuk keperluan perkawinan yang ditetapkan keluarga perempuan menjadi penyebab adanya kawin lari dalam masyarakat Bugis. ${ }^{13}$

Kawin lari tidak hanya dikenal dalam beragam komunitas masyarakat Indonesia. Kawin lari juga ditemukan dalam komunitas masyarakat di dunia lain. Di Amerika Utara juga dikenal tindakan kawin lari (runaway weddings) seperti dikemukakan Benlafquih. ${ }^{14}$ Adapun di Kyrgyzstan, model kawin lari dikenal dengan pola mencuri calon isteri dan dipandang tidak bermasalah di tengah masyarakat.15 Di Pakistan, kawin lari (eloped marriages) mengalami peningkatan setiap tahunnya karena berbagai alasan. ${ }^{16}$ Seperti digambarkan di Distrik Chitral Provinsi Khyber Pakhtunkwa, bahwa kawin lari di wilayah itu di antaranya disebabkan karena adanya keharusan eksogami dan larangan bagi warga Muslim untuk menikah dalam suku yang sama. ${ }^{17}$ Masyarakat Pakistan umumnya menganggap kawin lari ini sebagai ketidaktaatan dan terkadang hasilnya adalah pembunuhan demi menjaga dan mempertahankan kehormatan.

Berdasarkan uraian di atas, jenis penelitian ini adalah penelitian lapangan yang berlokasi di komunitas masyarakat Ranah Batahan Pasaman Barat Provinsi Sumatera Barat. Sumber data yang digunakan adalah sumber data

\footnotetext{
${ }^{13}$ Ahmad Pattiroy dan Idrus Salam, "Tradisi Doi' Menre' dalam Pernikahan Adat Bugis di Jambi," Al-Ahwal:Jurnal Hukum Keluarga Islam 1, no. 1(2016): 89-116.

${ }^{14}$ Christine Benlafquih, Shareef, dan Amina, "Cultural Influences Oblige Parents to Stage Lavish Wedding even at the Risk of Facing Financial Hardships," Islamic Horizons, 2007.

15Lesia Nedoluzhko dan Victor Agadjanian, "Between Tradition and Modernity: Marriage Dynamics in Kyrgyzstan," Demography 52, no. 3 (2015): 861-82, https://doi.org/10.1007/s13524015-0393-2.

${ }^{16}$ Arshad Munir dan Naseem Akhter, "Marriage in Islam: An Analytical Study With a Special Focus on Non-Traditional Marriages in Pakistan," FWUJournal of Social Sciences 12, no. 2 (2018): 179-89.

${ }^{17}$ Arab Naz et al., "Traditional Wedding System and Marriage by Elopement among Kalasha Tribe of District Chitral, Khyber Pakhtunkhwa, Pakistan," FWU Journal of Social Sciences 9, no. 1 (2015): 5969.
} 
primer dan sekunder. Data primer dikumpulkan melalui observasi perkawinan pasca marlojong, wawancara mendalam dengan pasangan yang melakukan marlojong, orang tua masing-masing pasangan, keluarga inti lainnya, tetua adat, pejabat KUA dan ulama lokal. Adapun data sekunder diperoleh melalui buku maupun naskah hasil penelitian yang telah dipublikasi dalam berbagai jurnal. Data dianalisis dengan cara reduksi, display dan verifikasi sesuai dengan langkah yang dikemukakan oleh Miles dan Huberman.18 Secara lebih spesifik, tujuan dari naskah ini adalah untuk mempelajari dan mengungkapkan lebih jauh tentang tradisi marlojong sebelum perkawinan dalam masyarakat Ranah Batahan Pasaman Barat.

\section{Rantau Ranah Batahan}

Kabupaten Pasaman Barat merupakan salah satu dari 19 kabupaten yang ada di Sumatera Barat. Secara geografis, kebudayaannya termasuk dalam budaya Suku Minangkabau. Dalam tambo Minangkabau, Pasaman Barat merupakan daerah rantau dan bukan darek (asli). Walaupun termasuk rantau, Kabupaten Pasaman Barat merupakan bagian dari wilayah budaya Minangkabau. Ada tiga suku besar yang mendiami daerah ini yaitu Minangkabau, Mandahiling dan Jawa. Suku Minangkabau kebanyakan berdiam di sebagian besar wilayah Kecamatan Talamau, Sasak Ranah Pasisia, Pasaman, Koto Balingka, Sungai Beremas, Kinali dan Luhak Nan Duo. Suku Mandahiling umumnya tinggal di wilayah Kecamatan Lembah Melintang, Sungai Aur, dan Ranah Batahan. Suku Jawa tersebar di berbagai kecamatan, seperti Kecamatan Pasaman di daerah Jorong Bandarejo, Jambak dan Tongar, kemudian di Kinali wilayah Sidomulyo dan Sumber Agung, di Kecamatan Luhak Nan Duo juga ada di daerah Kampung Lima, Puja Rahayu, Koto Baru dan Padang Lawas, dan di Kecamatan Ranah Batahan wilayah Desa Baru. ${ }^{19}$ Keragaman suku dan budaya di Pasaman Barat, khususnya wilayah Ranah Batahan, memberi pengaruh pada kehidupan harian masyarakat setempat. Keragaman budaya ini juga terlihat dalam kegiatan perkawinan, mulai dari prosesi peminangan, pelaksanaan akad, walimah al-ursh dan tradisi-tradisi sesudahnya. Umumnya

\footnotetext{
18Matthew B. Miles dan A. Michael Huberman, Analisis Data Kualitatif, ed. oleh Tjetjep Rohendi Rohidi (Jakarta: UI Press, 1992).

19“Pasaman in Figure," 2017.
} 
hanya di Kecamatan Ranah Batahan Pasaman Barat dengan mayoritas etnis Mandahiling, sering terjadi peristiwa marlojong sebelum perkawinan. Tradisi ini yang membedakan masyarakat Ranah Batahan dengan masyarakat lain di wilayah Pasaman Barat. Meskipun ada corak perubahan tujuan marlojong yang sebelumnya menuju rumah keluarga yang disegani, tetapi ada kecenderungan terkini yang menunjukkan tujuan marlojong itu ke rumah tetua adat atau ulama lokal.

\section{Makna Marlojong}

Kata marlojong berasal dari bahasa Batak yang terdiri dari dua suku kata yaitu mar dan lojong. Kata "mar" berarti "ber" lalu melekat pada kata "lojong" yang berarti "berlari". Dengan demikian, kata marlojong artinya adalah berlari. Dalam pemahaman sebagian masyarakat Ranah Batahan, kata marlojong ialah seorang laki-laki yang berlari dengan seorang perempuan menuju rumah salah seorang kerabatnya atau ke tempat seseorang yang mereka anggap bisa menyelesaikan maksud dan tujuan mereka untuk melaksanakan pernikahan..$^{20}$ Marlojong dalam pemahaman masyarakat lainnya adalah perkawinan dengan cara lari bersama. Seorang gadis dan seorang laki-laki berlari menuju rumah pemuka adat, kemudian pihak laki-laki mengadakan pertemuan kerabat, dan mengirim utusan untuk menyampaikan permohonan maaf dan memohon penyelesaian yang baik dari pihak kerabat perempuan. Kemudian diadakan perundingan dengan mengikuti tata tertib adat marlojong di wilayah itu. ${ }^{21}$ Dalam pengertian lain, marlojong adalah larinya seorang pria dan seorang perempuan dengan ditemani oleh seorang kerabat/temannya, atau tidak ditemani sama sekali untuk melakukan perkawinan tanpa adanya peminangan terlebih dahulu. Sebelum lari, keduanya telah bersepakat untuk melakukan pelarian itu. Marlojong dilakukan tanpa sepengetahuan kedua orang tua mereka. Pelarian ini dilakukan secara diam-diam tanpa diketahui oleh masyarakat umum. Di samping itu, marlojong ini dapat juga diartikan sebagai suatu bentuk perkawinan yang didahului oleh perbuatan seorang laki-laki yang membawa lari seorang perempuan atau sebaliknya, karena di antara mereka benar-benar saling mencintai dan telah berkeinginan sungguh-

\footnotetext{
20Wawancara dengan sekelompokmasyarakat Ranah Batahan pada September 2017.

${ }^{21}$ Sution Usman Aji, Kawin Lari dan Kawin Antar Agama (Yogyakarta: Liberty, 1989).
} 
Salma, Syahril

sungguh untuk mewujudkan kehidupan rumah tangga, sedangkan ibu bapak mereka tidak merestui.

Pada umumnya, marlojong terjadi karena keengganan orang tua (ibu-bapak) menikahkan anak mereka dengan pasangan yang dipilihnya. Oleh karena itu, proses khitbah (lamaran) secara resmi dilakukan setelah marlojong terjadi. Marlojong menurut adat adalah pelarian seorang perempuan bersama seorang laki-laki ke rumah kepala adat atau kerabat laki-laki yang disegani untuk meminta persetujuan dari orang tua perempuan melalui musyawarah adat di antara kepala adat dengan kedua orang tua masing-masing pasangan. Musyawarah adat itu merumuskan kesepakatan penyelesaian masalah dan persetujuan antara kedua belah pihak ${ }^{22}$ Ada juga masyarakat yang mengatakan bahwa marlojong itu dikatakan sebagai perkawinan tanpa ada kegiatan pertunangan adat secara resmi antara kedua pasangan. Meskipun demikian, ada juga pihak keluarga dari kedua pasangan yang membantu terjadinya tradisi marlojong dan akibat sesudahnya. ${ }^{23}$ Ada juga masyarakat yang mengatakan bahwa marlojong adalah di antara bentuk pemberontakan anak terhadap orang tuanya yang bersikukuh mematuhi adat peminangan dan perkawinan yang dipandang memberatkan karena besarnya beban finansial (parobanan) di dalamnya.

\section{Sebab-sebab Marlojong}

Pada dasarnya, proses perkawinan di Ranah Batahan sesuai dengan ketentuan agama (Islam), adat dan negara. Biasanya, proses ini didominasi oleh tradisi setempat karena aturan agama dan negara biasanya hanya terkait dengan persoalan akad nikah di KUA. Selain itu, mulai dari khitbah sampai pesta perkawinan, dilakukan tradisi perkawinan yang telah berlangsung secara turun temurun di wilayah itu. ${ }^{24}$ Ada di antara tradisi itu yang dipandang sebagian masyarakat memberatkan, seperti tingginya parobanan (uang hantaran), sementara agama meringankannya. Menurut penjelasan masyarakat, parobanan pada dasarnya merupakan uang yang ditetapkan oleh keluarga perempuan dan harus dibayar/dipenuhi oleh calon mempelai laki-laki. Uang ini, menurut

\footnotetext{
22Wawancara dengan beberapa Tetua Adat masyarakat Ranah Batahan pada September 2017.

23Wawancara dengan keluarga yang menerima pasangan marlojong pada Oktober 2017.

24Wawancara dengan Ketua KUA Kecamatan Lembah Melintang pada Oktober 2017.
} 
sebagian masyarakat, digunakan untuk keperluan kenduri perkawinan, mulai dari biaya perlengkapan kamar tidur sampai biaya penyediaan makanan untuk seluruh tamu undangan. Ada juga masyarakat yang mengatakan jika mahar termasuk ke dalam parobanan ini. Meskipun demikian, parobanan umumnya digunakan untuk kedua keperluan di atas. ${ }^{25}$ Melihat penjelasan masyarakat, satu paket lengkap parobanan itu bernilai sangat tinggi bagi masyarakat yang memiliki anak laki-laki sebagai penyedia. Ketika ada ibu bapak yang melihat calon suami anaknya memiliki status sosial yang tinggi maka pihak perempuan menetapkan standar parobanan yang tinggi pula. Demikian juga ketika ibu bapak tidak/kurang menyukai pilihan anak perempuannya maka jalan untuk mencegah pernikahan mereka adalah dengan menetapkan standar parobanan yang tinggi pula.

Berdasarkan penjelasan masyarakat tersebut, marlojong menjadi pilihan untuk keluar dari tradisi itu. Oleh karena itu, sebab-sebab terjadinya marlojong di antaranya yaitu; pertama, adanya ketidaksetujuan (keengganan) ibu bapak menerima calon suami/isteri anaknya. ${ }^{26}$ Ada beberapa faktor yang dapat menjadi penyebab keengganan ibu bapak menikahkan anaknya. Status sosial dan ekonomi calon pasangan menjadi penyebab pertama keengganan ibu bapak. Dalam banyak kasus marlojong, ditemukan bahwa orang tua pihak perempuan beranggapan bahwa anaknya tidak setara (kafa'ah) dengan laki-laki atau keluarganya dari segi sosial maupun ekonomi. ${ }^{27}$ Dalam kasus lain juga ditemukan keengganan ibu bapak karena adanya perbedaan status anak perempuannya yang masih gadis dengan laki-laki duda yang menyukainya. ${ }^{28}$ Ada juga keengganan ibu bapak yang disebabkan oleh laki-laki yang menginginkan anak perempuannya tidak memiliki pekerjaan yang jelas, sehingga muncul kekhawatiran terhadap pelalaian kewajiban nafkah lahir anak perempuannya setelah perkawinan.29 Ditemukan juga keengganan ibu bapak karena mereka ingin menjodohkan anak perempuannya dengan laki-laki lain yang mereka sukai. ${ }^{30}$

\footnotetext{
25Wawancara dengan anggota keluarga yang membayar parobanan pada November 2017.

26Wawancara dengan Ibu pasangan marlojong pada Oktober 2017.

27Wawancara dengan Ayah dan Ibu pasangan marlojong pada November 2017.

28Wawancara dengan Ayah pasangan marlojong pada November 2017.

29 Wawancara dengan Ayah pasangan marlojong pada Oktober 2017.

30 Wawancara dengan Ayah dan Ibu pasangan marlojong pada November 2017.
} 
Salma, Syahril

Kedua, putusan ibu bapak masing-masing pihak keluarga dalam menetapkan parobanan. Ketika seorang laki-laki tidak sanggup membayar parobanan yang ditetapkan orang tua perempuan dan pihak laki-laki telah meminta secara baik-baik agar nilainya diturunkan tetapi permintaan itu tetap tidak dipenuhi, maka marlojong menjadi cara menurunkan nilai parobanan itu. Ketentuan adat tentang uang hantaran (parobanan atau tuhor) pada masyarakat Ranah Batahan cukup beraneka ragam. Hal ini tidak lepas dari faktor ekonomi dan sosial budaya masyarakat itu sendiri. Oleh karena itu, besaran parobanan bisa menjadi satu penyebab terjadinya marlojong sebelum perkawinan. Marlojong itu dapat menurunkan harga diri keluarga perempuan, khususnya gadis itu yang berakibat pada turunnya nilai parobanan.

Seorang perempuan yang pernah melakukan marlojong, dianggap tidak baik di tengah masyarakat. Jalan terbaik adalah menikah dengan laki-laki yang berlari bersamanya. Tingkat pendidikan menjadi faktor kedua yang memicu keengganan ibu bapak menikahkan anaknya. Ditemukan kasus tentang adanya pendidikan perempuan lebih tinggi dari pendidikan laki-laki yang menginginkannya, sehingga orang tua perempuan menjadikan itu sebagai alasan keengganan. ${ }^{31}$ Mereka berharap anak perempuannya bisa menikah dengan orang yang setara atau lebih tinggi tingkat pendidikannya. Ada juga ditemukan kasus keengganan orang tua karena anak perempuannya masih duduk di bangku sekolah, dan mereka berharap anaknya menyelesaikan sekolahnya terlebih dahulu. ${ }^{32}$ Agama dan kehidupan keagamaan (kesalehan) seseorang di Ranah Batahan ini juga dapat menimbulkan keengganan ibu bapak menikahkan anaknya. Orang tua perempuan tidak merestui laki-laki pilihan anaknya karena sangat dangkal pengamalan nilai-nilai agamanya, bahkan ada orang tua perempuan yang mengatakan jika mereka tidak menyetujui pilihan anaknya karena laki-laki itu tidak mendirikan salat dan kewajiban-kewajiban utama agama lainnya.

\section{Prosesi Marlojong}

Suatu perkawinan yang ditentang orang tua dapat terjadi setelah melalui tradisi marlojong. Pada awalnya, pihak laki-laki melakukan pendekatan kepada

\footnotetext{
${ }^{31}$ Wawancara dengan pasangan marlojong pada November 2017.

32Wawancara dengan pasangan marlojong pada Oktober 2017.
} 
pihak perempuan untuk memulai proses lamaran secara adat. Dalam proses pendekatan itu, pihak laki-laki menemukan kesulitan yang berujung pada keengganan pihak perempuan untuk menerimanya. Keadaan ini juga bisa terjadi sebaliknya, yaitu keengganan pihak laki-laki menerima perempuan pilihan anaknya setelah dilakukan pendekatan adat sebelum lamaran. Kemudian mereka pergi meninggalkan rumahnya masing-masing menuju suatu tempat yang disepakati dan memungkinkan mereka untuk mendapatkan persetujuan. ${ }^{33}$ Secara umum, tempat yang dipilih untuk melarikan diri adalah rumah tetua adat atau rumah kerabat yang paling disegani dan bisa membantu mereka melunakkan hati ibu bapaknya agar menyetujui perkawinan itu.

Prosesi marlojong pada tradisi masyarakat Ranah Batahan sering terjadi pada malam hari. Pelarian mereka tidak diketahui oleh orang tua dan keluarga lainnya. Hal ini mereka lakukan untuk menghindarkan diri dari pandangan orang banyak. Meskipun demikian, ada juga marlojong yang terjadi pada siang hari ketika orang tua mereka sedang tidak berada di rumah. Marlojong dilakukan dengan laki-laki melalui tiga cara, pertama, laki-laki secara langsung menjemput perempuan itu di rumahnya dengan ditemani oleh salah seorang kerabat yang menyetujui untuk dibawa lari menuju rumah tetua adat atau kerabat yang disegani. ${ }^{34}$ Kedua, dalam kasus lain, penjemputan itu dilakukan oleh orang yang dipercayai oleh laki-laki yang akan marlojong dan dibawa ke rumah tetua adat yang telah ditunggu oleh laki-laki yang melarikannya. Ketiga, marlojong dilakukan dengan cara membuat perjanjian untuk bertemu di suatu tempat dan pada waktu yang mereka sepakati, kemudian berangkat bersama ke rumah tetua adat atau kerabat yang disegani. ${ }^{35}$

Proses selanjutnya, keluarga laki-laki atau tetua adat tempat mereka melakukan marlojong, memberitahukan dan menyampaikan kepada orang tua, baik dari pihak laki-laki maupun dari perempuan, bahwa anak mereka telah melakukan marlojong dan berkeinginan untuk dinikahkan. ${ }^{36}$ Ada beberapa kemungkinan yang terjadi setelah tetua adat atau kerabat yang disegani memberitahu tentang marlojong anak mereka. Pertama, pelaksanaan

\footnotetext{
33Wawancara dengan laki-laki yang melakukan marlojong pada September 2017.

${ }^{34}$ Wawancara dengan Tetua Adat yang menerima pasangan marlojong pada November 2017.

35Wawancara pasangan marlojong pada Oktober 2017.

36Wawancara dengan Tetua Adat dan keluarga inti pasangan marlojong pada November 2017.
} 
perkawinan mereka diserahkan kepada tetua adat atau kerabat yang disegani dengan tidak dihadiri oleh orang tua yang tidak menyetujui. Hal ini terjadi ketika orang tua tidak memaafkan perbuatan mereka dan enggan menikahkannya. Walaupun wali perempuan enggan (wali 'adal) menikahkan anaknya setelah marlojong, namun orang tua (ayah) pihak perempuan menyerahkan dan mewakilkan perwalian anak perempuannya kepada tetua adat atau kerabat yang disegani sesuai dengan tempat mereka melakukan marlojong. Kedua, ketika orang tua kedua belah pihak bersedia memaafkan perbuatan anak mereka dan merelakan marlojong yang sudah terjadi, maka mereka kembali kepada orang tua masing-masing. Artinya, keengganan wali teratasi dengan marlojong. Dalam hal ini, keluarga pihak laki-laki berkewajiban untuk melaksanakan khitbah secara benar sesuai dengan adat yang berlaku di Ranah Batahan. Mereka datang menemui orang tua dan keluarga perempuan untuk memusyawarahkan segala sesuatu terkait dengan persyaratanpersyaratan yang harus dipenuhi, baik secara adat, agama, maupun ketentuan hukum perundang-undangan yang berlaku. Sehingga perkawinan pasca marlojong tersebut dapat diselesaikan dengan baik tanpa harus ke pengadilan agama.

Apabila peristiwa marlojong terjadi di Ranah Batahan Kabupaten Pasaman Barat, maka pemangku adat bisa menyelesaikan dan menerima mereka secara adat setelah kedua orang tua laki-laki dan perempuan memaafkan perbuatan mereka dan bersedia menerima mereka kembali. Beberapa tetua adat di Ranah Batahan menjelaskan tata cara adat menyelesaikan persoalan marlojong yang dilakukan oleh pasangan yang tidak direstui ibu bapaknya. ${ }^{37}$ Pertama, tetua adat memanggil kedua orang tua mereka dan tetua adat meminta mereka untuk menemui ninik mamak (saudara laki-laki ibu sebagai pemangku adat) masing-masing dan mengemukakan masalah anak mereka yang sudah melakukan marlojong. Mereka mengajukan permohonan agar masalah marlojong anaknya segera diselesaikan dan mereka diterima kembali secara adat. Kedua, kedua belah pihak harus memenuhi ketentuan adat yang sudah menjadi kesepakatan di tengah masyarakat. Setiap kasus marlojong di Ranah Batahan berujung pada penyembelihan satu atau dua ekor kambing sesuai kesepakatan kedua keluarga. Kambing tersebut dimasak dan dimakan

\footnotetext{
37Wawancara dengan Tetua Adat pada November 2017.
} 
secara bersama di rumah perempuan dengan cara mengundang seluruh perangkat adat, seperti ninik mamak, pemangku adat suku lain yang ada di wilayah itu, imam/khatib masjid, alim ulama, dan tokoh masyarakat lainnya.

Ketiga, tetua adat menyampaikan tujuan utama undangan, yaitu pemberitahuan peristiwa marlojong dan diakhiri dengan rekonsiliasi (perdamaian) adat, baik antara kedua keluarga calon mempelai maupun antara kedua keluarga dengan masyarakat sekitarnya. Tetua adat menegaskan bahwa setelah dilakukan rekonsiliasi adat, maka masing-masing elemen masyarakat yang hadir dalam undangan itu diharapkan bisa memberitahukan kepada masyarakat di lingkungannya masing-masing, sehingga tidak ada lagi anggota masyarakat yang mempertanyakan status marlojong mereka. Ketiga, di akhir pertemuan, tetua adat melakukan upa-upa dengan cara memanggil laki-laki dan perempuan yang telah melakukan marlojong dan meresmikan penerimaan mereka kembali secara adat. ${ }^{38}$ Dengan berakhirnya upa-upa, maka mereka telah resmi diterima secara adat dan dapat melangsungkan pernikahan setelahnya.

\section{Akibat Marlojong}

Setiap perbuatan dengan sebab-sebab tertentu pasti memiliki akibat tersendiri. Demikian juga keputusan pasangan untuk melakukan marlojong sebelum perkawinan juga memberi akibat tertentu, baik terhadap diri mereka sendiri maupun terhadap keluarga (khususnya orang tua) masing-masing, terutama ayah perempuan. Pertama, secara pribadi, marlojong adalah keputusan yang tidak begitu baik dalam pandangan masyarakat umumnya. Keputusan ini menggambarkan lemahnya ikatan orang tua dan anak, sehingga komunikasi di antara mereka tidak berjalan lancar, utamanya ketika anak hendak mengambil keputusan menikah sebagai keputusan terbesar dalam hidupnya. Pada sisi lain, marlojong ini juga dapat menghadirkan rasa malu ibu bapak di tengah masyarakat. Rasa malu yang muncul dari sikap anak perempuannya yang bersedia dilarikan dan rasa malu dari sikap anak lakilakinya yang telah melarikan anak perempuan orang, meskipun itu ke rumah

\footnotetext{
2019.

38Observasi pelaksanaan perkawinan pasangan pasca marlojong pada September dan November
} 
tetua adat maupun rumah salah seorang keluarga yang disegani. Kedua, marlojong juga memberi akibat hukum, baik terhadap hukum adat di wilayah tersebut maupun hukum Islam yang telah mengatur perkawinan sedemikian rupa sampai dalam aturan bernegara. Akibat-akibat ini bisa dilihat dari sisi baik dan juga dari sisi buruk menurut agama dan adat.

Apabila seorang laki-laki dan seorang perempuan telah memutuskan untuk melakukan marlojong, maka keputusan itu menunjukkan telah terjadi keengganan wali (wali 'aḍl) untuk menikahkan anak perempuannya dengan laki-laki yang disukainya. Oleh karena itu, marlojong merupakan cara adat yang ditempuh pasangan untuk melunakkan hati ayah dan ibunya. Beban menanggung malu di tengah masyarakat sangat kuat, sehingga tekanan itu mampu mengalahkan keengganan orang tua untuk menikahkan anak perempuannya. Setelah marlojong dilakukan, pernikahan secepatnya dilakukan dan lebih cepat dari proses pernikahan biasa di wilayah tersebut, sebagaimana dituturkan oleh beberapa tetua adat. ${ }^{39}$ Dalam hal ini, tetua adat secara terbatas mengambil alih kekuasaan wali yang enggan untuk menikahkan anaknya seperti layaknya hakim pengadilan agama yang mengambil alih kewenangan seorang ayah sebagai wali ketika dia enggan menikahkan anaknya.

Tetua adat merupakan orang yang sangat dihormati di wilayah ini, sehingga marlojong yang dilakukan di rumahnya menunjukkan bahwa ibu bapak yang enggan menikahkan anaknya dapat dilunakkan hatinya. Pada akhirnya, pasangan yang melakukan marlojong tidak perlu pergi ke pengadilan agama untuk menyelesaikan masalah mereka. Dalam pemikiran umum masyarakat Ranah Batahan, menyelesaikan kasus di pengadilan agama jauh lebih buruk dibanding marlojong yang diselesaikan secara adat. Menurut sebagian masyarakat, pengadilan agama merupakan tempat untuk bercerai dan bukan tempat bagi seorang anak perempuan untuk bersengketa dengan ibu bapak ${ }^{40}$ Oleh karena itu, tetua adat lebih diutamakan orang untuk menyelesaikan urusan-urusan adat mereka sekalipun secara bernegara, ada lembaga khusus untuk menyelesaikan urusan keengganan wali dalam perkawinan ini. Umumnya, kedua orang tua (keluarga) mereka memaafkan perbuatan marlojong ini, sehingga selalu ada kemungkinan untuk diresmikan

\footnotetext{
${ }^{39}$ Wawancara dengan Tetua Adat pada November 2017.

40Wawancara dengan keluarga inti pasangan marlojong pada Oktober 2017.
} 
dan diselesaikan secara adat dan negara. Biasanya mereka diterima kembali oleh orang tua mereka dan bersedia memenuhi ketentuan adat pasca marlojong.

Akibat lain yang ditimbulkan oleh perbuatan marlojong adalah penurunan nilai kewajiban parobanan. Ketentuan parobanan pada masyarakat Ranah Batahan berbeda-beda, ada yang kecil, menengah dan ada yang tinggi. Hal ini tergantung pada kondisi perempuan yang dilamar, baik dari sisi strata sosial maupun pendidikan, pekerjaan, dan status lainnya. Orang tua perempuan biasanya menetapkan parobanan ini tergantung pada kondisi laki-laki yang melamar, baik sisi kemampuan finansial maupun kematangan pekerjaan. Hal ini berkaitan juga dengan restu dari orang tua perempuan. Dalam beberapa kasus ditemukan ada orang tua perempuan yang tidak menyetujui laki-laki pilihan anaknya, sehingga mereka menetapkan parobanan dengan standar yang lebih besar atau tinggi dengan tujuan agar laki-laki itu mengurungkan niat untuk menikahi anaknya. Oleh sebab itu, muda-mudi masyarakat Ranah Bantahan berpikiran bahwa hanya dengan marlojong, ketentuan besaran parobanan tersebut dapat dikurangi. ${ }^{41}$

Tradisi marlojong ini dilakukan untuk meringankan pihak laki-laki atas ketidaksanggupannya membayar parobanan yang diminta oleh pihak perempuan. Sementara itu, Islam tidak menganjurkan memberikan bayaran yang tinggi, karena besaran mahar sebagai salah satu kewajiban laki-laki, tidak boleh membebaninya untuk menikah. Walaupun Islam tidak menetapkan berapa banyak mahar yang harus diberikan kepada calon istri, tetapi pemberian mahar diserahkan menurut kemampuan yang bersangkutan disertai kerelaan dan persetujuan masing-masing pihak yang akan menikah untuk menetapkan jumlahnya. Islam tidak menetapkan jumlah minimum dan maksimum dari mahar karena perbedaan tingkatan kemampuan manusia dalam memberinya. Orang yang kaya mempunyai kemampuan untuk memberi mahar yang lebih besar jumlahnya kepada calon istrinya, sebaliknya orang yang miskin ada yang hampir tidak mampu memberinya. Oleh karena itu, banyaknya mahar itu tidak dibatasi oleh syariat Islam, melainkan menurut kemampuan calon suami dan kerelaan calon istri untuk menerima mahar yang diberikan. Demikian juga biaya untuk melaksanakan kenduri. Rasulullah mengingatkan seorang sahabat yang

\footnotetext{
41 Wawancara dengan pasangan marlojong pada November 2017.
} 
Salma, Syahril

menikah, agar dia menyelenggarakan kenduri, meskipun dengan biaya sederhana. Meskipun demikian, kadang-kadang masyarakat adat memerlukan kenduri lebih besar untuk menjaga harga diri mereka di tengah masyarakat seperti yang dipraktikkan di wilayah Ranah Batahan.

\section{Marlojong dalam Sudut Pandang Hukum Islam}

Ayah dan ibu adalah orang yang paling dimuliakan oleh Allah, sehingga dalam ayat tertentu disebutkan bahwa setelah kewajiban untuk hanya mengabdi kepada-Nya diperintahkan untuk bersyukur dan berbuat baik kepada ibu bapak. Di sisi lain, ketika seorang anak, khususnya perempuan, beranjak dewasa, seorang ayah memiliki hak untuk menikahkannya dengan lelaki terbaik pilihannya. Meskipun demikian, seorang anak juga memiliki hak untuk menerima atau menolak pilihan ayahnya sesuai dengan ketentuan syariat. Jalan keluar yang diberikan oleh negara adalah melalui gugatan wali 'adal ke pengadilan agama sebagaimana diatur dalam Pasal 23 Angka (1) dan (2) Kompilasi Hukum Islam. Hakim pengadilan agama dapat menilai secara syarak lelaki terbaik untuk anak perempuan tersebut. Dalam hal ini, hakim melalui pengadilan agama dapat mengambil alih kewenangan ayah sebagai wali dan memindahkannya pada wali hakim untuk menikahkan anak perempuannya.

Banyak alasan ibu bapak untuk menolak calon suami pilihan anaknya. Di antara alasan keengganan ibu bapak di Ranah Batahan yaitu karena status calon pasangan itu di tengah masyarakat. Hal ini menunjukkan bahwa status memiliki peran yang penting di tengah masyarakat, sebagaimana dikemukakan oleh Yakin, karena bisa berujung pada perceraian. ${ }^{42}$ Selain itu, pilihan untuk kawin lari tidak hanya disebabkan oleh keengganan orang tua karena status sosial, tetapi juga karena pilihan orientasi seksual yang berbeda dari orang kebanyakan ${ }^{43}$ dan usia anak yang masih belia..4 Jika diikuti makna

\footnotetext{
42Ayang Utriza Yakin, "The Register of the Qadi Court 'Kiyahi Pĕqih Najmuddin' of the Sultanate of Banten, 1754-1756," Studia Islamika 22, no. 3 January 2016): 443-86, https://doi.org/ 10.15408/sdi.v22i3.2354.

43Koeswinarno Koeswinarno dan Mutolehudin Mustolehudin, "Islam, gay, and marginalization: a study on the religious behaviours of gays in Yogyakarta," Indonesian Journal of Islam and Muslim Societies 7, no. 1 (Juni 2017): 125-52, https://doi.org/10.18326/ijims.v7i1.125-152.

44Kasjim Salenda, "Abuse of Islamic Law and Child Marriage in South-Sulawesi Indonesia," AlJami'ah: Journal of Islamic Studies 54, no. 1 (2016): 95-121, https://doi.org/10.14421/ ajis.2016.541.95-121.
} 
kawin lari yang dilakukan jauh dari kediaman orang tua dan dengan wali perempuan yang juga tidak diketahui hubungannya dengan pihak perempuan atau bahkan pernikahan itu tidak dicatatkan, maka secara umum marlojong tidak termasuk pada jenis kawin lari seperti ini. Marlojong umumnya adalah semata cara adat menyelesaikan keengganan wali untuk menikahkan anaknya tanpa mereka harus mengajukannya ke pengadilan agama. Dalam kajian Mubarok disebutkan bahwa hakim pengadilan agama menilai perbuatan kawin lari yang juga telah dikenal dalam praktik hukum di masyarakat suku Makassar, khususnya di wilayah Kabupaten Takalar, bukanlah suatu kebiasaan yang baik, sehingga tidak tergolong 'urf șahịh, melainkan 'urf fäsid, yang tidak dapat dijadikan sebagai alat ber-istidlāl atau landasan normatif dalam pengambilan keputusan hukum. ${ }^{45}$ Demikian juga dalam pandangan masyarakat Lombok, bahwa kawin lari ini adalah hal yang dianggap memalukan dan pasangan itu mendapatkan sanksi sosial dari masyarakat. ${ }^{46}$

Adapun marlojong tidak bisa sepenuhnya dipandang sebagai sesuatu yang buruk, karena adat parobanan yang tidak ditetapkan harus demikian dalam agama, menjadi faktor yang memberatkan padahal agama mengingatkan agar pernikahan itu dimudahkan. ${ }^{47}$ Salah satu kemudahan itu adalah dengan membolehkan mahar yang bernilai rendah tetapi disetujui oleh kedua belah pihak. Oleh karena itu, mendahulukan agama dari adat tidak harus menjadi sesuatu yang memalukan. Demikian juga, mendahulukan adat dalam rangka menyelesaikan sengketa keagamaan (perkawinan) juga boleh untuk dilakukan demi tercapainya tujuan-tujuan agama yaitu membangun kemaslahatan masyarakat.

\section{Simpulan}

Secara harfiah, marlojong memang bermakna kawin lari atau menikah dalam pelarian, tetapi pada dasarnya, marlojong tidak bisa sepenuhnya disebut

\footnotetext{
45Nafi' Mubarok, "Living Law dan 'Urf Sebagai Sumber Hukum Positif di Indonesia," Islamica: Jurnal Studi Keislaman 11, no. 1 (2016): 135-58, https://doi.org/10.15642/islamica.2016.11.1.135158.

46Baiq Rizka Herliana, Ni Wayan Arya Utami, and Desak Putu Yuli Kurniati, "Early Marriage Practices and the Health Impacts on Female Adolescent Health in Central Lombok: A Qualitative Study," Public Health and Preventive Medicine Archive 6, no. 1 (2018): 61-67, https://doi.org/ 10.15562/phpma.v6i1.11.

47Wawancara dengan ulama lokal pada November 2017
} 
Salma, Syahril

demikian seperti yang dipahami umumnya masyarakat. Marlojong lebih kepada sikap dan tindakan anak untuk mendapatkan persetujuan perkawinan dari orang tuanya. Hal ini dilakukan demi menghindari atau menurunkan nilai parobanan, karena akad nikah itu sendiri tetap dilakukan di rumah ibu bapaknya, rumah saudara ibu yang disegani atau rumah tetua adat atas kesepakatan kedua orang tua pasangan setelah memenuhi ketentuan adat berbentuk sanksi upa-upa. Marlojong secara substantif merupakan cara yang efektif untuk menghindari sengketa wali 'aḍl di pengadilan agama dan tetua adat mewakili elemen itu sebagai penengah antara ayah dan anak perempuannya serta antara dua keluarga pasangan yang melakukan marlojong.[a]

\section{BIBLIOGRAFI}

Aji, Sution Usman. Kawin Lari dan Kawin Antar Agama. Yogyakarta: Liberty, 1989.

Benlafquih, Christine, Shareef, dan Amina. "Cultural Influences Oblige Parents to Stage Lavish Wedding even at the Risk of Facing Financial Hardships." Islamic Horizons, 2007.

Fauzi, Ahmad. "Pemikiran Ibn Hazm tentang Keberadaan Wali Nikah dalam Perkawinan Janda." Al-Ihkam: Jurnal Hukum dan Pranata Sosial 8, no. 2 (2014): 300-333. https://doi.org/10.19105/al-ihkam.V8I2.352.

Herliana, Baiq Rizka, Ni Wayan Arya Utami, dan Desak Putu Yuli Kurniati. "Early marriage practices and the health impacts on female adolescent health in Central Lombok: a qualitative study." Public Health and Preventive Medicine Archive 6, no. 1 (Juli 2018): 61-67. https://doi.org/ 10.15562/phpma.v6i1.11.

Huzaimah, Arne. "Pandangan Hakim Pengadilan Agama Palembang terhadap Putusan Mahkamah Konstitusi Nomor 46/PUU-VIII/2010 tentang Status Anak di Luar Nikah." Intizar 20, no. 1 (2014): 63-82.

Ismail, Abdul Fattah Wan, Hasnizam Hashim, Syahirah Abdul Shukor, dan Asma Harun. "Faraq Perkahwinan bagi Pasangan Tak Sah Taraf di Negeri Sembilan - Judicial Separation of Illegal Marriage In Negeri Sembilan." International Journal of Islamic Thought 13, no. June (2018): 124-34. https://doi.org/10.24035/ijit.13.2018.012.

Koeswinarno, Koeswinarno, dan Mutolehudin Mustolehudin. "Islam, gay, and marginalization: a study on the religious behaviours of gays in 
Yogyakarta." Indonesian Journal of Islam and Muslim Societies 7, no. 1 (2017): 125-52. https://doi.org/10.18326/ijims.v7i1.125-152.

Kudhori, Muhammad. "Hak Perempuan dalam Memilih Suami (Telaah Hadis Ijbār Wali)." Al-Ihkam: Jurnal Hukum dan Pranata Sosial 12, no. 1 (2017): 1-23. https://doi.org/10.19105/al-ihkam.v12i1.1213.

Maharaja, Nurol Huda binti Pehin Datu Seri. "Wali Nikah dalam Fiqh dan Penerapannya dalam Undang-Undang Keluarga Islam Brunei (Pindaan 2012)." Nurani: Jurnal Kajian Syari'ah dan Masyarakat 17, no. 1 (2017): $1-14$.

Miles, Matthew B., dan A. Michael Huberman. Analisis Data Kualitatif. Diedit oleh Tjetjep Rohendi Rohidi. Jakarta: UI Press, 1992.

Mubarok, Nafi'. "Living Law dan 'Urf sebagai Sumber Hukum Positif di Indonesia." Islamica: Jurnal Studi Keislaman 11, no. 1 (2016): 135-58. https://doi.org/10.15642/ISLAMICA.2016.11.1.135-158.

Munir, Arshad, dan Naseem Akhter. "Marriage in Islam: An Analytical Study With a Special Focus on Non-Traditional Marriages in Pakistan." FWU Journal of Social Sciences 12, no. 2 (2018): 179-89.

Naz, Arab, Irum Sheikh, Waseem Khan, dan Gohar Saeed. "Traditional Wedding System and Marriage by Elopement among Kalasha Tribe of District Chitral, Khyber Pakhtunkhwa, Pakistan." FWU Journal of Social Sciences 9, no. 1 (2015): 59-69.

Nedoluzhko, Lesia, dan Victor Agadjanian. "Between Tradition and Modernity: Marriage Dynamics in Kyrgyzstan.” Demography 52, no. 3 (2015): 86182. https://doi.org/10.1007/s13524-015-0393-2.

"Pasaman in Figure," 2017.

Pattiroy, Ahmad, dan Idrus Salam. 'Tradisi Doi' Menre' dalam Pernikahan Adat Bugis di Jambi." Al-Ahwal: Jurnal Hukum Keluarga Islam 1, no. 1 (2016): 89-116.

Saladin, Bustami. “Tradisi Merari' Suku Sasak di Lombok dalam Perspektif Hukum Islam." Al-Ihkam: Jurnal Hukum dan Pranata Sosial 8, no. 1 (2014): 21-39. https://doi.org/10.19105/al-ihkam.V8I1.338.

Salenda, Kasjim. "Abuse of Islamic Law and Child Marriage in South-Sulawesi Indonesia." Al-Jami'ah: Journal of Islamic Studies 54, no. 1 (2016): 95121. https://doi.org/10.14421/ajis.2016.541.95-121.

Setiawan, Eko. "Fenomena Nikah Siri dalam Perspektif Sosiologi Hukum." Justicia Islamica 13, no. 1 (2016): 135-55. https://doi.org/10.21154/ justicia.v13i1.456. 
Salma, Syahril

Sudantra, I Ketut, I Made Walesa Putra, dan Yuwono Yuwono. "Aspek-aspek Hukum Keluarga dalam Awig-Awig Desa Pakraman.” Jurnal Magister Hukum Udayana (Udayana Master Law Journal) 5, no. 1 (2016): 43-58. https://doi.org/10.24843/JMHU.2016.v05.i01.p05.

Syahrial Haq, Hilman, dan Hamdi Hamdi. "Perkawinan Adat Merariq dan Tradisi Selabar di Masyarakat Suku Sasak." Perspektif 21, no. 3 (2016): 157-67. https://doi.org/10.30742/perspektif.v21i3.598.

Tulab, Tali. "Tinjauan Status Wali dalam Perkawinan Berdasar Pendekatan Feminis." Ulul Albab: Jurnal Studi dan Penelitian Hukum Islam 1, no. 1 (2017): 152-64. https://doi.org/10.30659/jua.v1i1.2223.

Wagianto, Ramdan. "Tradisi Kawin Colong pada Masyarakat Osing Banyuwangi Perspektif Sosiologi Hukum Islam." Al-Ahwal: Jurnal Hukum Keluarga Islam 10, no. 1 (2017): 61-84. https://doi.org/ 10.14421/ahwal.2017.10106.

Yakin, Ayang Utriza. "The Register of the Qadi Court 'Kiyahi Pĕqih Najmuddin' of the Sultanate of Banten, 1754-1756." Studia Islamika 22, no. 3 (Januari 2016): 443-86. https://doi.org/10.15408/sdi.v22i3.2354.

Yelepele, Umar, dan Moh. Hefni. "Perkawinan Adat Muslim Suku Dani di Papua." Al-Ihkam: Jurnal Hukum dan Pranata Sosial 7, no. 1 (2013): 1751. https://doi.org/10.19105/al-ihkam.V7I1.317.

Observasi pelaksanaan perkawinan pasangan pasca marlojong pada September dan November 2019.

Wawancara dengan sekelompok masyarakat Ranah Batahan pada September 2017.

Wawancara dengan beberapa Tetua Adat masyarakat Ranah Batahan pada September 2017.

Wawancara dengan keluarga yang menerima pasangan marlojong pada Oktober 2017.

Wawancara dengan Ketua KUA Kecamatan Lembah Melintang pada Oktober 2017.

Wawancara dengan anggota keluarga yang membayar parobanan pada November 2017.

Wawancara dengan Ibu pasangan marlojong pada Oktober 2017.

Wawancara dengan Ayah dan Ibu pasangan marlojong pada November 2017.

Wawancara dengan Ayah pasangan marlojong pada November 2017. 
Wawancara dengan Ayah pasangan marlojong pada Oktober 2017.

Wawancara dengan Ayah dan Ibu pasangan marlojong pada November 2017.

Wawancara dengan pasangan marlojong pada November 2017.

Wawancara dengan pasangan marlojong pada Oktober 2017.

Wawancara dengan laki-laki yang melakukan marlojong pada September 2017.

Wawancara dengan Tetua Adat yang menerima pasangan marlojong pada November 2017.

Wawancara dengan pasangan marlojong pada November 2017.

Wawancara dengan pasangan marlojong pada Oktober 2017.

Wawancara dengan laki-laki yang melakukan marlojong pada September 2017.

Wawancara dengan Tetua Adat yang menerima pasangan marlojong pada November 2017.

Wawancara dengan Tetua Adat pada November 2017.

Wawancara dengan keluarga inti pasangan marlojong pada Oktober 2017.

Wawancara dengan pasangan marlojong pada November 2017.

Wawancara dengan ulama lokal pada November 2017. 
66 || Vol 29, No 1, April 2019 